保健物理. 5. $63 \sim 68$ (1970)

\title{
個人用塵埃サンプラの特性試験
}

\author{
大 畑 勉**，本 郷 昭三*，鈴木間左支*
}

(1970年 3 月 8 日 受理)

\section{A Study on the Characteristics of Some Personal Air Samplers}

\author{
By Tsutomu OHATA**, Shozo HONGO* and Masashi SUZUKI*
}

This report describes the results of the test for sampling characteristics of some personal air samplers which are widely used for estimating the hazard due to inhalation of airborne harmful materials in the nuclear fuel plants and other industrial installations.

The personal air samplers investigated are three kinds, namely, of the trade mark of MSA Monitaire Sampler, UNICO Mighty Mite and Casella MK II.

In order to measure the flow rate of each sampler, a transducer was calibrated by means of other experimental procedure, before the flow rate tests were made. The battery capacity without the load and the maximum load under the constant voltage supply were also studied.

The maximum flaw-rate without the load was about $5 \mathrm{l} / \mathrm{min}$ in the UNICO, $4 \mathrm{l} / \mathrm{min}$ in the MSA and $2 l / \mathrm{min}$ in the Casella, respectively. The sampling air volume of the UNICO sampler is, however, most decreased by the increase of load, compared with those of the Casella and the MSA samplers.

Some other basic data useful for improving the characteristics of samplers were also obtained.

\section{I. 序論}

一般に，有害物により污染された空気の有害度を評価 するために，作業施設内の一定のところに設置されたタ スト・モニタにより有害物の空気中灌度測定值が使用さ れているが，この測定值をもってただちに施設内で各作 莱者が平均的に呼吸する空気中有害物の湍度であると考

*放射線医学総合研究所嫄境得生研究部：千涑市穴川 4-9-1 (National Institute of Radiological Sciences : 1-94 Anagawa, Chiba-shi)

淡現在：日本原子力研究所 保健物理女全管理部：茨城県那珂郡 東海村 (Present Adress: Div. Health Physics and Safety, Japan Atomic Energy Research Institute: Tokai-mura, Naka-gun, Ibaraki-ken)
えることは，発整源の位置，作策者の動き，室内空気の 流れ，場所による換気状態の差異などの要因とその定置 モニタの設置位置や集壁方法などとの関係から考えて， 必ずしも买当でない場合が多く，各作業者の吸入被䀧量 を適切に評価出来ない場合が多い。

そこで, 現時点で上述の諸因子を包括する1方法とし て，各作業者個人が作業中に自ら搰帯し，かつ出来るだ け鵕口に近、場所で空気中の有害粉㢈を採集しうる個人 用鷹埃サンブラが開発されていることは龒知の 事であ る。

個人用庭埃サンブラは，一般に汇紙を使用して空気中 濃度を評価しているか，使用した沪紙の抵抗，電池容 量，発㾝時間的変動なそによって，一定時間内に吸 
引される全空気量に差が生してくる。

そこで，今回の試験は，サンブラを使用する上で留意 すへき事唄を得る事と, 負荷などが若干变動しても出来 るた゚け一定容量で，しかもより人間の呼吸量（作業内谷 個人間の相異によって变化する）に近い流量を吸引しう るサンブラを閒発するための基礎的データを得る事を目 的として行った。

\section{II. 試験方法および結果}

\section{1. 試駿に供したサンブラ}

本試験に用いた 3 種類のサンブラの写真を Fig. 1 に 示す。

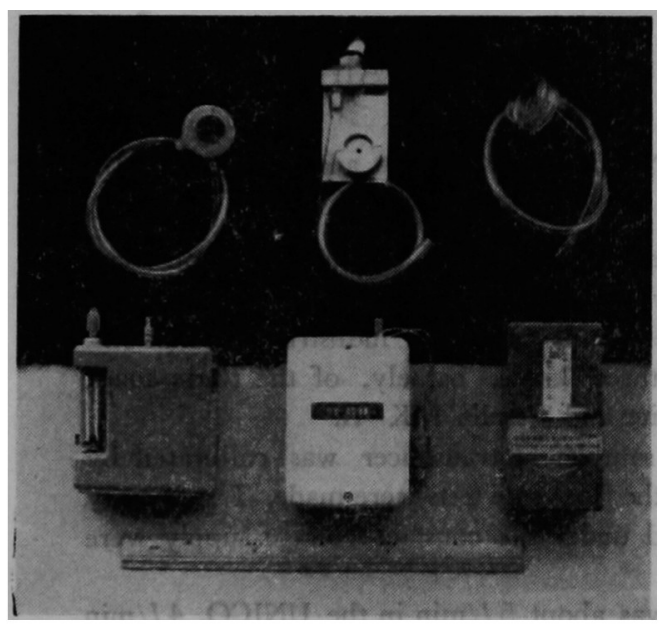

Fig. 1 View of the personal air samplers used for the capacity test

Right: UNICO Mighty Mite Air Sampler (Model 440)

Middle: Casella Personal Dust Sampler MK II

Left: Mine Safety Appliances Monitaire Sampler

サンブラの吸引形式には, ファン式122ももあるが，抵 抗の高、汇紙や濃度の高、空匃、中㸮鷹を長時間集蝔する 事に道さない。これに比べ 1 枚のタイヤフラムの往復運 動で吸引する方法が，現在，世界的に広く使用されてい 3。

今回試験に用いた 3 理類のサンブラは, 全てこの形式 である。Casella に使用されているタイヤフラムの材質 は, 合成コムである。そして,フレオンを使用している サンブラ3も報告されている。

\section{2. 流量校正}

ボンフの报動数，活量なとを連続的に测定できるトラ
ンス・ジューサ MFP $1 \mathrm{~T}$ (抵抗 $2.5 \mathrm{mmH}_{2} \mathrm{O} / l / \mathrm{sec}$, 最 大流量 $2 l / \mathrm{sec}$, 日本光電製) を, 流量測定に使用した。 流量校正の方法を Fig. 2 に示す。困において上部に

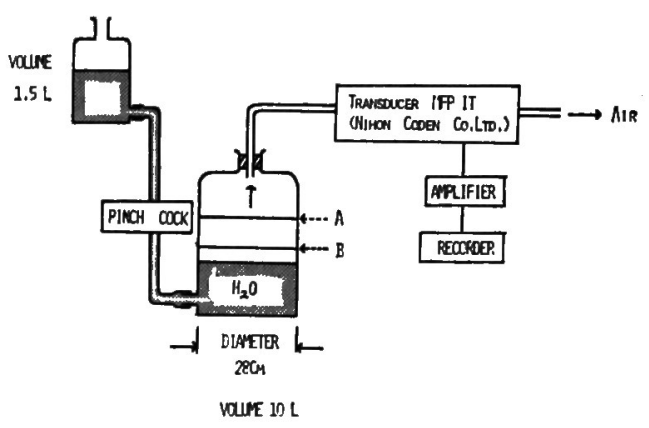

Fig. 2 Eqperimental diagram for the calibration of flow rate

置、た $1.5 \ell$ のビンより目的の空気流量になるよう，ビ ンチコックで水量を調節し，下部においたヒン（容䅡10 $\ell$, 底面直径 $28 \mathrm{~cm})$ にB点より $1 \ell$ になるA点を通過 するまでの時間を湖定して校正をおこなった。

\section{3. 無角荷時の電池電压の路下試験}

3 機種ともニッケル・カドニウム電池を使用している が，吸引される空気量は電池の变化に影帮される。そこ で汇紙などの抵抗をいっさい加えない（無負荷）条件 で，サンブラのみ可動させた場合の電地電王の降下試験 をおこなった。

その結果を Fig. 3 に示す。可動前の電圧は, UNICO

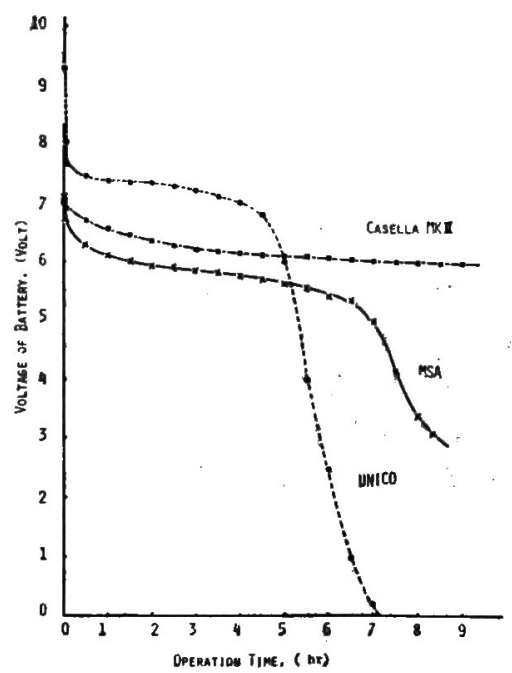

Fig. 3 Change of battery voltage vs operation time of the personal air samplers 
で約 $9.2 \mathrm{~V}$ と一鄱く， MSA は $7.1 \mathrm{~V}$, Casella は $6.9 \mathrm{~V}$ であった。可動直後の電王降下は，UNICO で約 $1.8 \mathrm{~V}$ と最も低下し, ついで MSA の $0.5 \mathrm{~V}$, Casella の $0.2 \mathrm{~V}$ である。Casella の場合，9時間経た後の電池 電王は $6 \mathrm{~V}$ までしか降下していない。

\section{4. 一定電王の角荷と吸引流量との関係}

この試験は Fig. 4に示す試駼系でおこない, MSA と

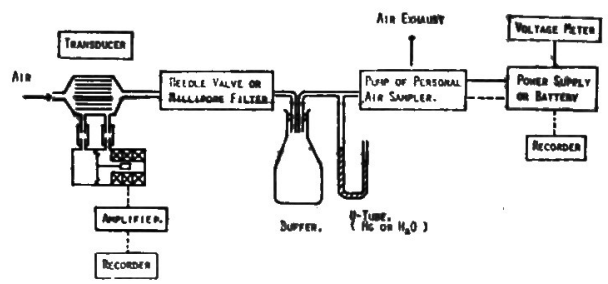

Fig. 4 Experimental diagram for the capacity test of personal air samplers

UNICO に対しては 7.5V で, Casella は $6 \mathrm{~V} の 一$ 定電

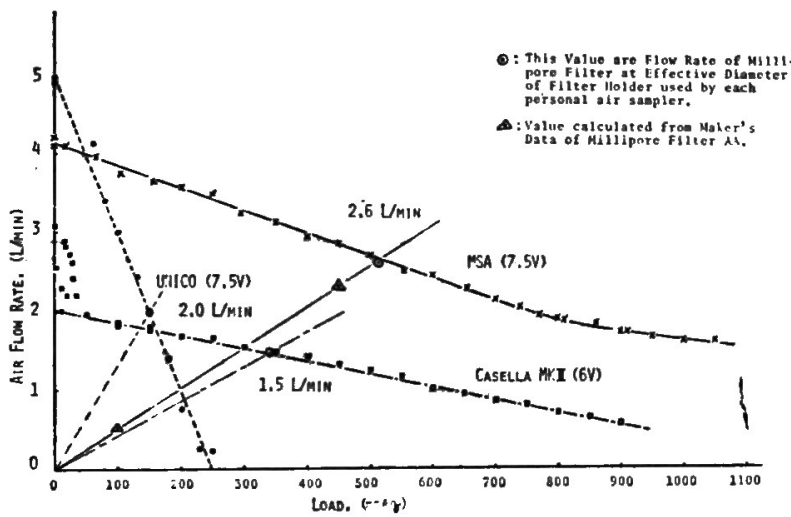

Fig. 5 Decreasing of the flow rate by load

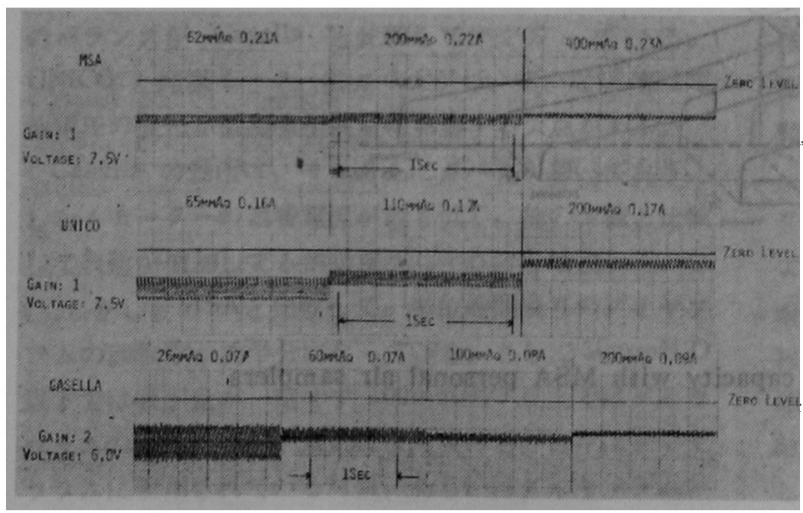

Fig. 6 Pattern of air flow in suction in three different kinds of personal samplers
压を加えておこなった。この時サンブラに用いられてい、 る電池は使用せずに外部電源を使用した。

サンブラに加える鱼荷を調整するために，ニードル・ ハルブを使用した。加わわる負荷の生力降下を湘定する ために，サンプラの直前にU 字管を装入した。

またミりボア・フィルタ AA の流量と抵抗を湘定し た。この際用いたフィルタの大きさは，それぞれのサン ブラに用いられているホルダーの集㢈直径と同一であ る。

その結果を Fig. 5 に示めすが, Casella の場合, 負 荷が $50 \mathrm{mmH}_{2} \mathrm{O}$ 以下の吸引量は $2 \sim 3 l / \mathrm{min}$ の閒こハ ラついて安定性に久けている。約 $900 \mathrm{~mm} \mathrm{H}_{2} \mathrm{O}$ で約 0.5 $l / \mathrm{min}$ の吸引能力を持っている。

UNICO の場合は, 無負荷時の吸引量が最も多く約 5 $l / \min に も$ 速しているが，負荷の増加によって著しく流 量に影整し，䄪 $250 \mathrm{mmH}_{2} \mathrm{O}$ 前後で停止した。

MSA の無負荷時の流量は, 䄪 $4.1 \mathrm{l} / \mathrm{min}$ UNICO より小くないが，約 $1500 \mathrm{mmH}_{2} \mathrm{O}$ まで喛引可能である ことが判った。

ミリボア・フィルタ AA の流量と抗抵の試駼 結は, Casella で $1.5 l / \mathrm{min}\left(340 \mathrm{mmH}_{2} \mathrm{O}\right)$, UNICO で $2 l / \mathrm{min}\left(150 \mathrm{mmH}_{2} \mathrm{O}\right), \mathrm{MSA}$ は 2.6 $l / \mathrm{min}\left(515 \mathrm{mmH}_{2} \mathrm{O}\right)$ であった。

\section{5. 一定電昍時のサンブラの吸引状態}

脈動を平滑化する系を除、て，4 と同棣の電王 で，2，3の負荷時におけるそれぞれのサンブラに ついて，タィヤフラムの振動数, 消費電流を湘定 した。

その結果を Fig. 6 に示す。UNICO は負荷が 增加するとタイヤフラムの振幅が顕著に減少して いる。振動数および 消費電流は， MSA で 62 $\mathrm{mmH}_{2} \mathrm{O}$ の時 50 回/sec, $0.21 \mathrm{~A}$, UNICO は65 $\mathrm{mmH}_{2} \mathrm{O}$ で48回/sec, $0.16 \mathrm{~A}$, Casella は $60 \mathrm{~mm}$ $\mathrm{H}_{2} \mathrm{O} て ゙ 30$ 回/ sec，0.07A であった。また 3 種類の サンプラとも負荷が增加すると消費電流は若千增 加の傾向を示めしている。

\section{6. 無負荷時の供給電压と流量との関係}

それぞれのサンブラへの供給電圧を MSA と Casella の場合 $7.5 \mathrm{~V}$ まで，UNICO は 9V まで 変化させ，可動䍏始電王および流量を測定した。

その結果を Fig. 1 に示す。UNICO と MSA は 電生が增加寸るに椾、，ほほ直線的に流量は增加 している。これに対し Casella は電圧を $5.5 \mathrm{~V}$ 以 
上增しても約 $2.6 l / \mathrm{min} の 一$ 定流冝になってい る。これはモーターに回転数を調整するカバナが 装着されていて，それが刘果を発趺ているもの と思もわれる。可動關始電王は，UNICO で約 $0.8 \mathrm{~V}, \mathrm{MSA} て ゙ 1 \mathrm{~V}$, Casella で $1.6 \mathrm{~V}$ 前後であ る。

\section{MSA における個々のサンブラの性能の比 較壾酸}

同一機種においても個々のサンブラ間で同し程 度の性能があるかどうかは，使用する上で重要で ある。そこで今回は 4 と同棣に負荷と流息との関 係について，供給電压を $7.5 \mathrm{~V}$ として試駼をおこ なった。

その結果を Fig. 8 に示すが，Fig. 5 と良く一 致しており，しかも相互間にそれほど差が生して いないことから同時期に彆作されたサンフラであ れば，同程度の性能を持っていると思われる。

MSA については, 当研究所において使用して いることから，試験結果を総合すると Fig. 9 の 特性図が得られた。この図において，直線 $\mathrm{AB}$

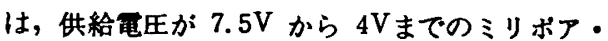
フィルタ AA の流量を表わしている。そこで， II-3の試駼粘果から, 使用時の電池電压は䄪 $7 \mathrm{~V}$ より，実際の使用時における開始流是を図上 より求めると約 $2.5 \mathrm{l} / \mathrm{min}$ ( $\mathrm{C}$ 点) となる。

以上の試験結果を， 3 種類のサンブラについて 比較するために Table 1 に示めした。

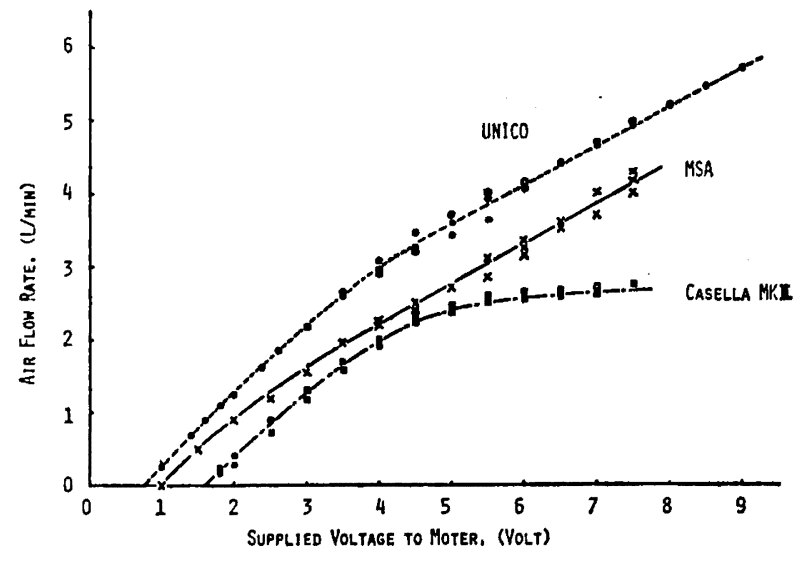

Fig. 7 Relation between the flow and supplied voltage to moter

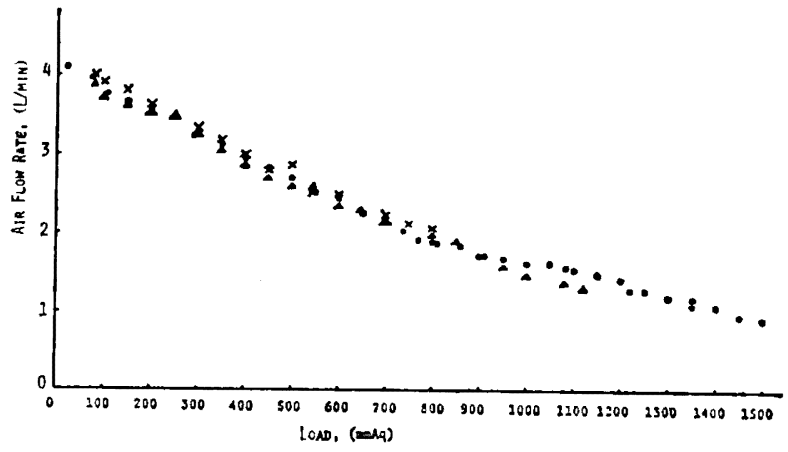

Fig. 8 Deviation of capacity among three MSA personal air samplers

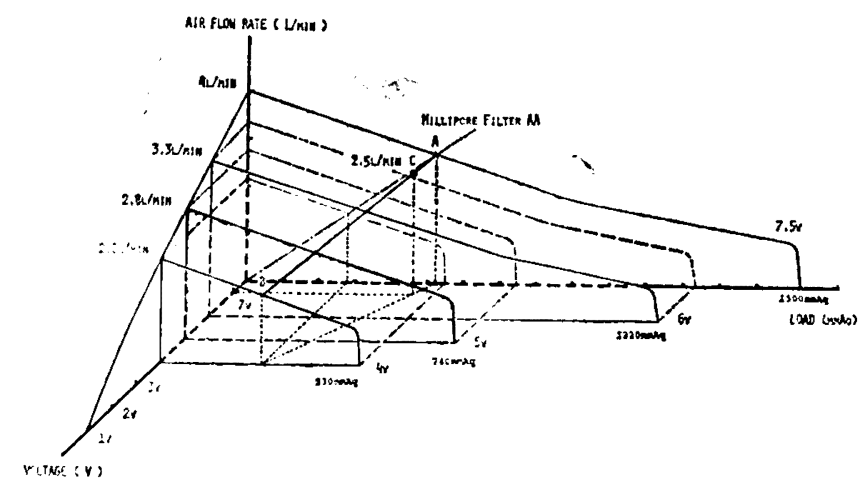

Fig. 9 Geometrical illustration of capacity with MSA personal air samplers 
Table 1. Results of the capacity test in three kinds of personal air sampler.

\begin{tabular}{|c|c|c|c|c|c|c|c|c|c|}
\hline & $\begin{array}{l}\text { Total } \\
\text { Weight. } \\
\text { (gram) }\end{array}$ & $\begin{array}{c}\text { Max. Volt. } \\
\text { of Battery } \\
\text { (Volt) }\end{array}$ & $\begin{array}{l}\text { Max. F. R. } \\
\text { without } \\
\text { Load. } \\
(l / \mathrm{min})\end{array}$ & $\left|\begin{array}{l}\text { Max. } \\
\text { Load } \\
\text { tolerated } \\
\left(\mathrm{mmH}_{2} \mathrm{O}\right)\end{array}\right|$ & \begin{tabular}{|l|} 
F. R. of \\
M. F. AA \\
used. \\
$\mathrm{V}(l / \mathrm{min})$
\end{tabular} & \begin{tabular}{|l} 
Ef fect. \\
Dia. of \\
Filter \\
Holder. \\
d (mm)
\end{tabular} & $\begin{array}{l}\text { Freque. } \\
\text { and Amp. } \\
\text { of Pump } \\
\text { at Load. } \\
\text { (Fre/sec) } \\
\text { (A) }\end{array}$ & \begin{tabular}{|l} 
Start. \\
Volt. of \\
Pump \\
without \\
Load. \\
(Volt)
\end{tabular} & $\begin{array}{l}\text { Sampling } \\
\text { Velocity. } \\
(\mathrm{cm} / \mathrm{sec})\end{array}$ \\
\hline $\begin{array}{l}\text { UNICO } \\
\text { Mighty } \\
\text { Mite. }\end{array}$ & 570 & 9.2 & $\begin{array}{c}4.8 \\
(7.5 \mathrm{~V})\end{array}$ & $\begin{array}{l}\text { about } \\
260 \\
(7.5 \mathrm{~V})\end{array}$ & $\left|\begin{array}{c}2.1 \\
150 \mathrm{~mm} \mathrm{H}_{2} \mathrm{O} \\
(7.5 \mathrm{~V})\end{array}\right|$ & 34 & $\begin{array}{c}48 \\
0.16 \mathrm{~A} \\
(65 \mathrm{~mm} \\
\left.\mathrm{H}_{2} \mathrm{O}\right)\end{array}$ & 0.8 & 3.9 \\
\hline $\begin{array}{l}\text { Casella } \\
\text { MK. II }\end{array}$ & 730 & 6.9 & $\begin{array}{c}213 \\
(6 \mathrm{~V})\end{array}$ & $\begin{array}{l}\text { about } \\
900 \\
(6 \mathrm{~V})\end{array}$ & $\left|\begin{array}{c}1.5 \\
340 \mathrm{mmH}_{2} \mathrm{O} \\
(6 \mathrm{~V})\end{array}\right|$ & 21 & $\begin{array}{c}30 \\
0.07 \mathrm{~A} \\
(60 \mathrm{~mm} \\
\left.\mathrm{H}_{2} \mathrm{O}\right) \\
\end{array}$ & 1.6 & 7.6 \\
\hline M.S.A. & 660 & 7.1 & $\begin{array}{c}4.1 \\
(7.5 \mathrm{~V})\end{array}$ & $\begin{array}{l}\text { about } \\
1500 \\
(7.5 \mathrm{~V})\end{array}$ & $\left|\begin{array}{l}2.6 \\
520 \mathrm{mmH}_{2} \mathrm{O} \\
(7.5 \mathrm{~V})\end{array}\right|$ & 21 & $\begin{array}{c}50 \\
0.21 \mathrm{~A} \\
(62 \mathrm{~mm} \\
\left.\mathrm{H}_{2} \mathrm{O}\right)\end{array}$ & 1.0 & 12.5 \\
\hline
\end{tabular}

Where

F.R. = Flow Rate.

Sampling Velocity $=V / \pi(d / 2)^{2}$

M.F.=Millipore Filter.

\section{III. 考 察}

UNICO の揭合，1台のみの試匴結果であり，しかも 今回試験に用いた电地が劣化している事も考えられるの で即座に断定出来ないか，短時間でしかも抵抗の低、沪 紙を装着して空気污染の有無を知る程度に使用される方 が良いと考える。しかも沪紙の材栄によっては，集鹿さ れるところが㙨つかの同心円上のみになされ，集鷹有奻 面稓は実際に用いられている汇紙の集臣面稓よりかなり 小さくなり負荷が急增加する场合が生し，吸引た 全量はさらに小さくなると思われる。

MSA はサンフラに用、られているモーターと電池と のハランスか：Casella と比較してやや劣っている。 UNICO と同棣モーターにガバナがついていない事は電

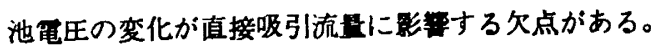

Casella の長所は，モーターにカガナか着いており， しかもモーターの消費雨硫か取も低く，他の 2 種と比較 して負荷が增加しても消塦電流はそれほと增加していな い。かし，MSAと比較して, 単位時間当りのタイヤフ ラムの回転数が約半分になっている。さらに $50 \mathrm{mmH}_{2} \mathrm{O}$ 以下では吸引量が一定せず $100 \mathrm{mmH}_{2} \mathrm{O}$ 以上ではダイヤ フラムの可動状狀が不規則になっている。これはダイヤ フラムに使用されている材筫，あるいはタイヤフラムの 可動機粠に難点があるためと思われる。

個人用サンフララの性能としては, 吸引性能が良いこと
も必要であるが，サンフララ自体の大きさ，形状および荲 早も大きな要因となる。その点，今回試験したサンブラ は䄪 $700 \mathrm{~g}$ 前後で作業能率の低下を引きおこすほどでは ないと考えられる。

以上の試験結果から判る㥞に，吸引量は電池签量，空 弎中の粉㾝量，ボンプの可動特性などによって，いちし るしく変化すると思もわれる。

そこで，現状のサンブラを使用して全吸引具を求める 場合，Fig. 9 に示す特性図を個々のサンブラについて 求めておき，集座開始から終了まで負荷と電池電压を測 定するか，あるいは流量を連続的に測定しなければ，よ り正確な全吸引旦は評価しえない。しかし，使用時に は，種々の制約が加わろので開始時と終了時の流量を測 定し，もって平均流量より全吸引量を算出することは現 時点ではやもえないと思われる。

あるサンブラを用いて㫦座する場合, フィルタ・ホル タの粠造, 面速度, 流線とホルタとの角度なとの因子に

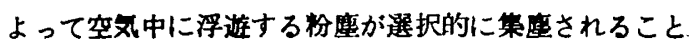
が, Walton(), Fuchs5) らによって示めされている。木 村2)は，柴田化学の個人用サンブラで煙灰，石英と電㥛 用のカーボンを粉鷹に用、て実駼的に試みている。その 結果によると，数 $10 \mu$ 以上の粗大粒子を含む粉鷹が浮遊 している埸合でも，サンフラに採取される䊉子の大きさ は，ほとんど 5 6 $\mu$ 以下であったと報告している。この 時の面速度は，最大でも $3 \mathrm{~cm} / \mathrm{sec}$ 前後と推定され，今 
回の試験中酷も低、UNICO (Table 1) より若干低、 が，同棣のことが今回試験をおこなったサンブラでも 起りうろと思もわれる。

したがって，個人用サンブラを使用して空気中淟度を 評価寸るさい，上述の因子のほかに，電池の回復能力， 作業時のボンブ特性，ホルタの装着位羁()などの影整を 十分考虑する必要があ。

現在の時点で改善するとすれば，

(1) 電池電圧の変動に対しモーターの回転数があまり

影䨩されないカバナ付モーターを使用する。

（2）サンブラの里量，大きさがやや增加しても，黾池 容岳とモーターの消费奄力とのハランスの均れたものに する。この点, 电池容国に限界があるので, 使用時間の 靔定が必要になる。

（3）タイヤフラムの材留の劣化が問題になり交換時期 を明喆すると共に，ょり劣化しにくい材筫を選択する必 要がある。

（4）負荷がある程度增加しても，タイヤフラムおよび 機械的な可動機棈などか円滑に作動する棣改善する。

\section{IV. 結 論}

以上の試験結果から

（1）UNICO は無負荷時に最も多量に吸引すろが，負
荷の変化に者しく影警される。

（2）MSA は吸引可能な敢大負荷で，他の 2 種類と比 較して優っており、ミリポア・フィル夕を䒾着した時も 吸引田が樶大值となった。しかし电池電圧の変化に伴な い流专が変化するので使用には注意を要する。

（3）Casella はMSA と比較して, 無負荷時の吸引岳, 負荷時の流量において劣っているか，モーターの消費电 力が最小でしかもカバナが装着されているなど，今回試 驗をおこなった中で，実用的であると云える。

しかし，吸引年など今だ改丵されるへさ点は多ふみう けられた。

\section{考文献}

(1) 木村苯二；労㑬科学， 41，(5), P. 239 (1965)

(2) 木村菌二; 労做科学, 43，(8), P. 443 (1967)

(3) R. J. Sherwood and D. M. S. Greenhalgh; Ann. Occup. Hyg. 2, 127 (1960)

(4) W. H. Walton; Brit.J. Appl. Phys. Suppl. Paper A. 5 No. 3, P. s 29-s 33. (1954)

(5) N. A. Fuchs ; "The Mechanics of Aerosols." P. 142-P151, Pergamon. (1964)

(6) B. B. Chatterjee. et al.; Amer. Ind. Hyg. Assoc. J., 30, 643 (1969)

\section{Société Française de Radioprotection からの会議開催案内}

当協誐会委員長宛，下記の案内がとどきましので御知らせいたします。

Dear Chairman,

I have the honour to inform you that the "Société Française de Radioprotection" will hold its Vth International meeting in Grenoble (Isère) from February 1 to 5, 1971. As president-elect of our Society I have been entrusted with the organization of this meeting, the general theme of which will be : Bone-seeking isotope contamination and radiation protection. The following subjects have been retained :

- metabolism of bone-seeking radionuclides

- assessment of bone burden and measurement of the delivered doses

- early and late biological effects on bone and hematopoietic tissues

- practical standards for radiation protection

- treatment of deposited bone-seeking radionuclides
The official languages will be french and english. An exhibition of scientific equipment will take place jointly.

Within a few weeks further information and registration forms will be circulated. You will receive some copies.

Yet, I would be very grateful to you if you could already announce this meeting to the members of your Society whom we warmly invite through your intermediary.

I thank you forward for it with kind regard, Yours sihcerely,

\section{AVARGUES}

S. F. R. P. President-elect

Congress General Secretary Centre d'Etudes Nucléaires

D. P. S. - B.P. $\mathrm{n}^{\circ} 6$

92-Fontenay-aux-Roses (France) 